\title{
E-Learning Berbasis Moodle Sebagai Media Informasi, Teknologi Dan Komunikasi Guna Mencegah Penyebaran COVID-19
}

\author{
Agus Zainudin ${ }^{1}$ \\ 1 University of Islamic Jember, Indonesia
}

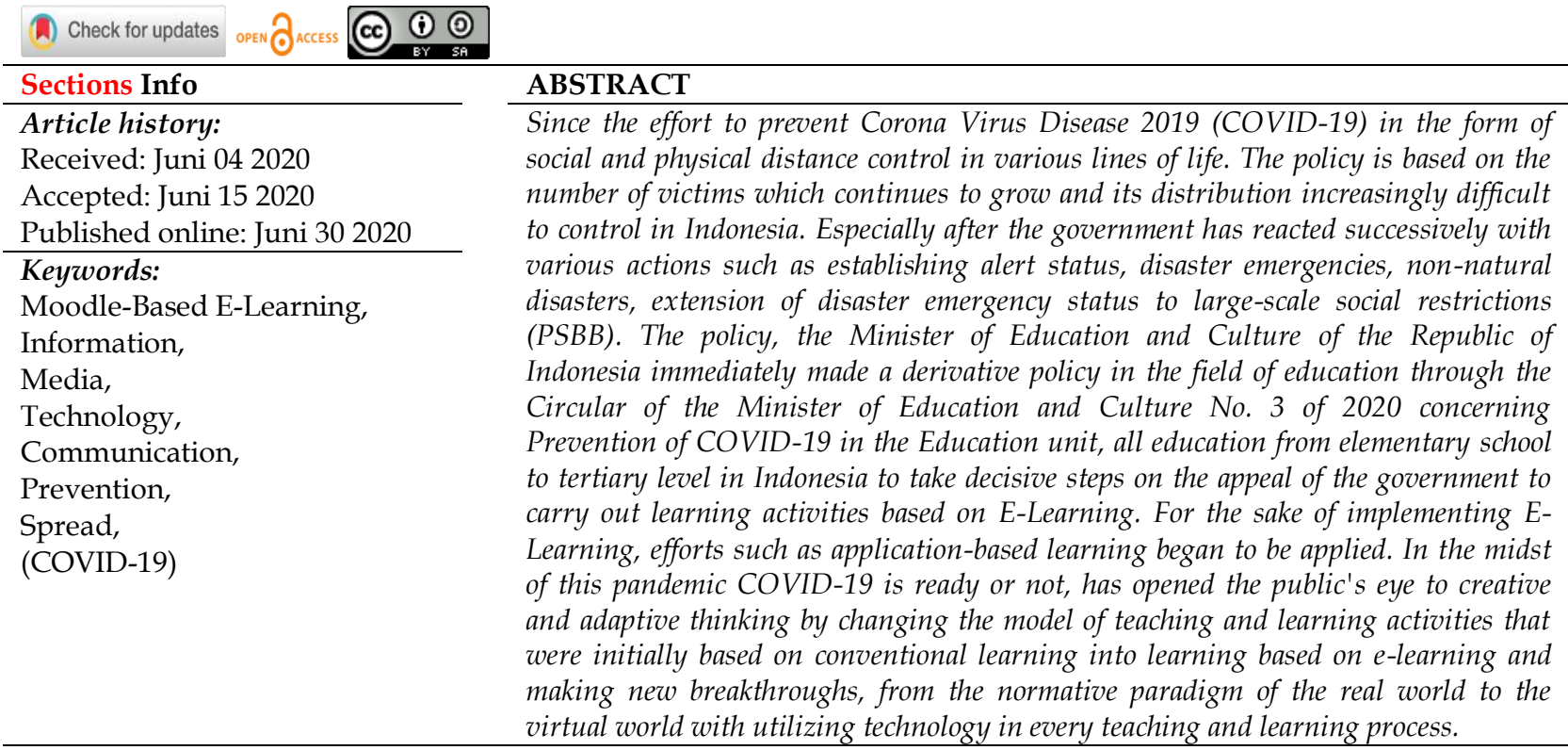

\section{INTRODUCTION}

Pandemi COVID-19 mengakibatkan Menteri Pendidikan dan Kebudayaan RI membuat kebijakan turunan dalam bidang pendidikan melalui Surat Edaran Mendikbud RI No 3 Tahun 2020 tentang Pencegahan COVID-19 pada satuan Pendidikan, semua pendidikan dari tingkat sekolah dasar s/d tinggi di Indonesia, tidak terkecuali satuan pendidikan negeri dan swasta mengambil langkah tegas atas himbauan pemerintah untuk melakukan aktivitas belajar dari rumah yang disebut ELearning. Demi menerapkan e-learning, maka Upaya seperti pembelajaran berbasis aplikasi mulai diterapkan.

Dengan fasilitas e-learning, libur sekolah bukan alasan untuk tidak belajar apalagi bagi yang siap-siap menghadapi ujian. Aplikasi ini juga tersedia gratis maupun berbayar bagi pengguna dari berbagai tingkat pendidikan. Berkembangnya Teknologi Informasi dan Komunikasi (TIK) yang semakin pesat, kebutuhan akan suatu konsep dan mekanisme belajar mengajar berbasis TI menjadi solusinya. Konsep yang kemudian terkenal dengan sebutan e-learning ini membawa pengaruh terjadinya proses transformasi pendidikan konvensional ke dalam bentuk digital, baik secara isi (contents) dan sistemnya.

E-learning dalam arti luas bisa mencakup pembelajaran yang dilakukan di media elektronik (internet) baik secara formal maupun informal. E-learning secara formal, misalnya adalah pembelajaran dengan kurikulum, silabus, mata pelajaran dan tes yang telah diatur dan disusun berdasarkan jadwal yang telah disepakati pihak-pihak terkait (pengelola e-learning dan pembelajaran sendiri). Pembelajaran seperti ini biasanya 
tingkat interaksinya tinggi dan diwajibkan oleh perusahaan pada karyawannya atau pembelajaran jarak jauh yang dikelola oleh sekolah dan perusahaan-perusahaan (biasnya perusahaan konsultan) yang memang bergerak di bidang penyedian jasa $e$ learning untuk masyarakat luas.

E-learning bisa juga dilakukan secara informal dengan interaksi yang lebih sederhana. Guru dapat memanfaatkan perkembangan teknologi informasi dalam melaksanakan sistem E-Learning sehingga proses pembelajaran dapat berjalan lancar walaupun tidak dilakukan secara tatap muka langsung. Pelaksanaan E-Learning dapat dilakukan dengan moodle video conference. Dalam video conference, pemberi materi dapat memberikan materi melalui audio dan visual secara langsung pada peserta didik atau siswa dan di lain sisi juga bisa mengurangi kontak bodi sehingga dapat mencegah penyebaran Covid-19.

Sehingga moodle video conference pada masa pandemi Covid-19 dapat digunakan sebagai media informasi, teknologi dan komunikasi dalam proses kegiatan belajar mengajar di semua tingkatan dari tingkat sekolah dasar s/d perguruan tinggi dan dapat mengurangi kontak bodi sebagai bentuk ikhtiyar dalam mencegah peyebaran Covid-19.

\section{RESEARCH METHOD}

Kajian dalam penelitian ini menggunakan jenis penelitian deskriptif kualitatif dengan menggunakan kajian kepustakaan/library research, data yang didapat mengenai E-learning berbasis moodle sebagai media informasi, teknologi dan komunikasi guna dalam mencegah penyebaran COVID-19, kemudian direduksi diambil kesimpulan berdasarkan penelitian, kajian terdahulu dan wacana yang dianalisis (konten analisis) secara mendalam terhadap persoalan yang terjadi.

\section{RESULTS AND DISCUSSION}

Dampak dari COVID-19 mengakibatkan sekolah menghentikan sementara pembelajaran dengan tatap muka, beralih menggunakan pemanfaatan fasilitas teknologi informasi dengan metode jarak jauh atau yang disebut e-learning. E-learning adalah teknologi informasi dan komunikasi untuk mengaktifkan peserta didik untuk belajar kapanpun dan dimanapun. E-learning berasal dari perpadanan dua kata yakni "e"dan"learning". "e" merupakan singkatan dari electronic dan learning adalah pembelajaran. Sehingga secara istilah maknanya adalah pembelajaran yang menggunakan media elektronik salah satunya dengan komputer. Internet merupakan perangkat penting dalam menggunakan e-learning (Yazdi, 2012:146).

Menurut Darin E. Hartley menyatakan bahwa e-learning merupakan suatu jenis belajar mengajar yang memungkinkan, tersampaikannya bahan ajar ke siswa dengan menggunakan media internet dengan mengkoneksikannya dengan jaringan di komputer lain. Menurut Tafiardi, e-learning merupakan pembelajaran dengan menggunakan jasa bantuan perangkat elektronik yang difokuskan pada proses belajar dengan menggunakan alat bantu berupa internet dan media elektronik (Intan Mutia dan Leonard, 2013:279).

Dari beberapa definisi di atas maka dapat disimpulkan bahwa e-learning merupakan sebuah hasil dari kemajuan teknologi yang dimanfaatkan dalam 
pembelajaran. Pelaksanaannya memanfaatkan media elektronik dan internet yang kemudian digabungkan dengan materi sesuai dengan kebutuhan peserta didik. Pembelajaran yang disampaikan pun dapat beragam modelnya, akan tetapi tetap dalam penyesuaian kurikulum pendidikan di Indonesia.

\section{CIRI DAN JENIS E-LEARNING}

E-learning merupakan salah satu bentuk model pembelajaran yang difaasilitasi dan didukung pemanfaatan teknologi informasi dan komunikasi. Ciri-ciri dari elearning adalah memiliki konten yang relevan dengan tujuan pembelajaran, menggunakan metode instruksional seperti contoh dan latihan dalam setiap pembelajarannya, menggunakan kata-kata dan gambar untuk menyampaikan materi pembelajaran, peserta didik diberikan kesempatan untuk belajar mandiri sehingga mampu membangun pemahaman dan ketrampilan yang baik (Numiek Sulistyo Hanum, 2013:92).

Selanjutnya, dalam independent learning yaitu peserta didik memiliki hak secara penuh untuk dapat mendapatkan keberhasilan pembelajaran dan membentuk pengetahuannya sendiri melalui pembelajaran mandiri. Hal ini juga mendukung adanya pelaksanakan kurikulum di Indonesia yang cenderung melibatkan peserta didik untuk menjadi obyek dalam kelas dan center dalam proses pengajaran. Manfaat selanjutnya yaitu e-learning memerlukan biaya yang terjangkau karena semuanya dikonsep menjadi hal yang ringkas dan simpel dalam sebuah teknologi yang dapat dimanfaatkan peserta didik. Selain itu, pembelajaran menggunakan E-learning tidak mengeluarkan banyak uang yang dikeluarkan untuk percetakan karena menggunakan teknologi digital dalam akses informasi dan penyampaian materi (Numiek Sulistyo Hanum, 2013:93).

Jenis e-learning menurut William Horton dalam bukunya yang berjudul "Technology and Tools for E-learning" yaitu lerned-led Elearning, facilititated E-learning, instructor-led E-learning, embedded E-learning, dan telementoring and e-coaching. Istilah tersebut memiliki makna dan pelaksanaan yang berbeda antara satu dengan yang lainnya. Learner-led E-learning yaitu sebuah pelaksanaan pembelajaran yang dirancang untuk memungkinkan peserta didik belajar secara mandiri dengan penuh tanggung jawab. Bedanya dengan computerbased training adalah peserta didik mempelajari materi yang sudah disediakan melalui CD-ROM atau DVD. Namun tidak dengan learnerled Elearning yang memberikan kebebasan kepada peserta didik untuk belajar secara independen dan mengakses informasi secara mandiri Mohammad Yazdi, (2012:147). Instructor-led E-learning menggunakan teknologi internet atau web untuk menyampaikan pembelajaran seperti pada kelas konvensional. Kebutuhan yang harus ada dalam jenis ini adalah video, audio, chatting, maupun bulletin board. Sedangkan facilitated E-learning merupakan kombinasi dari learned-led dan instructor-led E-learning. Pelaksanaannya yaitu menggunakan bahan belajar mandiri dalam beragam bentuk disampaikan melalui website dan diskusi melalui online yang tentunya membutuhkan akses internet (Mohammad Yazdi, 2012:149).

Embedded E-learning yaitu sebuah kategori yang berbeda dengan memberikan upaya agar terjadi just-in time training. Kategori pembelajaran yang memberikan bantuan secara cepat untuk dapat menguasai ketrampilan dan pengetahuan tertentu. 
Pelaksanaannya dapat dibantu dengan aplikasi program yang ditanam dalam website. Telementoring and e-coaching sebuah program bimbingan jarak jauh untuk memandu dan membimbing perkembangan peserta belajar dalam menguasai pengetahuan, ketrampilan atau sikap yang harus dikuasainya. Sama halnya dengan embedded Elearning. Namun, kebanyakan jenis ini banyak dimanfaatkan di perusahaan (I Putu Darmika, et. all. 2017:33).

Pelaksanaan e-learning terdapat beberapa komponen yaitu peserta didik yang merupakan tujuan dari dilaksanakan e-learning. Selanjutnya yaitu pendidik, seseorang yang akan menentukan rancangan pembelajaran. Kemudian dalam pelaksanaannya juga membutuhkan fasilitator, biasanya dalam sebuah instansi ini sering disebut dengan sarana prasarana yang akan menyediakan kebutuhan dalam pembelajaran dan memberikan fasilitas kepada pendidik maupun peserta didik. E-learning sebagai sebuah konsep yang memberikan kemudahan untuk dapat melaksanakan pembelajaran jarak jauh yang dapat dilaksanakan dimanapun dan kapanpun sehingga memungkinkan untuk melakukan aktivitas belajar tanpa ada interaksi fisik secara langsung dengan pendidik dan pelaksanaan pembelajaran dilaksanakan secara online dalam bentuk realtime off-line dan mengakses arsip (I Putu Darmika, et. all. (2017:35).

Oleh karena itu E-learning merupakan sebuah solusi untuk dapat memanfaatkan kemajuan teknologi dalam mengembangkan pengetahuan peserta didik. Sehingga pembelajaran tidak hanya sekedar mendengarkan penjelasan pendidik kemudian mengerjakan soal sebagai evaluasi. Namun, peserta didik juga akan mengakses secara mandiri pengetahuan yang ingin didapatkan dengan bimbingan pendidik dalam proses transfer ilmu.

\section{MANFAAT DAN KELEBIHAN E-LEARNING}

Manfaat e-learning menurut Pranoto, dkk adalah (Pranoto, Alvini.dkk, 2009:309).

a. Penggunaan e-learning untuk menunjang pelaksanaan proses belajar dapat meningkatkan daya serap mahasiswa atas materi yang diajarkan;

b. Meningkatkan partisipasi aktif dari mahasiswa.

c. Meningkatkan partisipasi aktif dari mahasiswa.

d. Meningkatkan kemampuan belajar mandiri mahasiswa.

e. Meningkatkan kualitas materi pendidik dan pelatihan.

f. Meningkatkan kemampuan menampilkan informasi dengan perangkat teknologi informasi, dimana dengan perangkat biasa sulit dilakukan.

Dari beberapa manfaat diatas dapat disimpulkan bahwa Pertama dari pembelajaran ini sangat Fleksibel. E-Learning memberi fleksibilitas dalam memilih waktu dan tempat untuk mengakses perjalanan. Kedua Belajar Mandiri, e-learning memberi kesempatan bagi pembelajar secara mandiri memegang kendali atas keberhasilan belajar, dan. Ketiga Efisiensi Biaya, e-learning memberi efisiensi biaya bagi administrasi penyelenggara, efisiensi penyediaan sarana dan fasilitas fisik untuk belajar dan efisiensi biaya bagi pembelajar adalah biaya transportasi dan akomodasi.

Adapun kelebihan Menurut L. Tjokro e-learning memiliki banyak kelebihan yaitu : 
a. Lebih mudah diserap, artinya menggunakan fasilitas multimedia berupa gambar, teks, animasi, suara, video.

b. Jauh lebih efektif dalam biaya, artinya tidak perlu instruktur, tidak perlu minimum audiensi, bisa dimana saja, bisa kapan saja, murah untuk diperbanyak.

c. Jauh lebih ringkas, artinya tidak banyak formalitas kelas, langsung pada pokok bahasan, mata pelajaran sesuai kebutuhan.

d. Tersedia 24 jam/hari-7 hari/minggu, artinya penguaasaan materi tergantung pada semangat dan daya serap siswa, bisa dimonitor, bisa diuji dengan e-test (L. Tjokro, Sutanto, 2009:140).

\section{KEKURANGAN E-LEARNING}

Selain kelebihan tentu ada pula kekurangan e-learning menurut yang diuraikan oleh Nursalam, (2008:140) sebagai berikut :

a. Kurangnya interaksi antara pengajar dan pelajar atau bahkan antar pelajar itu sendiri.

b. Kecenderungan mengabaikan aspek akademik atau aspek sosial dan sebaliknya membuat tumbuhnya aspek bisnis/komersial.

c. Proses belajar mengajar cenderung ke arah pelatihan daripada pendidikan.

d. Berubahnya peran pengajar dari yang semula menguasai teknik pembelajaran konvensional, kini juga dituntut mengetahui teknik pembelajaran yang menggunakan ICT (information, communication, dan technology).

e. Tidak semua tempat tersedia fasilitas internet (mungkin hal ini berkaitan dengan masalah tersedianya listrik, telepon, ataupun komputer).

f. Kurangnya sumber daya manusia yang menguasai internet.

g. Kurangnya penguasaan bahasa komputer.

h. Akses pada komputer yang memadai dapat menjadi masalah tersendiri bagi peserta didik.

i. Peserta didik bisa frustasi jika mereka tidak bisa mengakses grafik, gambar, dan video karena peralatan yang tidak memadai.

j. Tersedianya infrastruktur yang bisa dipenuhi.

k. Informasi dapat bervariasi dalam kualitas dan akurasi sehingga penduan dan fitur pertanyaan diperlukan.

1. Peserta didik dapat merasa terisolasi.

Kekurangan e-learning berbasis web menurut Munir sebagai berikut:

a. Kurangnya interaksi baik antara pengajar dengan pembelajar maupun antara pembelajar satu dengan yang lainnya. Hal ini terjadi karena dalam pembelajaran berbasis web, kelas dilakukan secara virtual sehingga interaksi yang dilakukan masih kurang. 
b. Terkadang lebih terfokus pada aspek teknologi daripada aspek pendidikannya. Produk e-learning merupakan hasil kemajuan teknologi sehingga masih banyak penggunanya yang belum memperhatikan aspek pendidikan yang digunakan di dalamnya.Proses pembelajaran akan terhambat, Jika pengajar tidak mengetahui dan menguasai strategi, metode, dan teknik pembelajaran berbasis teknologi informasi. Sangat diperlukan guru yang memahami kemajuan teknologi saat ini, agar pembelajaran yang dilakukan tetap up to date.

c. Sangat dibutuhkan motivasi dan kemampuan belajar mandiri yang tinggi dari pembelajar itu sendiri. Keberhasilan e-learning sangat bergantung pada kemauan belajar mandiri dari siswa, sehingga motivasi dari pembelajar juga sangat diutamakan dalam hal ini.

d. Tidak semua pembelajar dapat memanfaatkan semua fasilitas internet. Hal tersebut dikarenakan tidak semua sekolah memiliki fasilitas lengkap yang dapat digunakan siswa untuk mengakses internet.

e. Masih adanya keterbatasan ketersediaan software. Tidak semua software yang digunakan untuk mengembangkan e-learning dapat diperoleh dengan mudah oleh guru.

f. Masih kurangnya pengetahuan dan kemampuan dalam mengoperasionalkan komputer dan internet dengan baik. Hal tersebut dikarenakan terdapat perbedaan kemampuan dan pemahaman siswa maupun guru dalam mengoperasikan komputer maupun internet Munir, (2009:176).

Berangkat dari beberapa penjelasan di atas dapat disimpulakan bahwa kekurangan dari proses belajar e-learning ini yang pertama; Kurangnya interaksi antara pengajar dan siswa atau bahkan antara siswa itu sendiri, bisa memperlambat terbentuknya values dalam proses belajar mengajar. Kedua; Kecenderungan mengabaikan aspek akademik atau aspek sosial dan sebaliknya mendorong aspek bisnis atau komersial. Ketiga; Proses belajar dan mengajarnya cenderung ke arah pelatihan dari pada pendidikan. Keempat; Siswa yang tidak mempunyai motivasi belajar yang tinggi cenderung gagal. Kelima; Tidak semua tempat atau wilayah tersedia atau terjangkau internet dengan baik (berkaitan dengan masalah tersedianya listrik, telepon, dan komputer). Keenam; Kurangnya mereka yang mengetahui dan memiliki keterampilan dalam bidang komputer dan internet.

\section{E-LEARNING SEBAGAI PENCEGAH PENYEBARAN COVID-19}

Penejelasan di atas menjadi penunjang e-learning sebagai pencegah penyebaran covid-19. E-Learning yang dimaksudkan pembelajaran yang memiliki konten yang relevan dengan tujuan pembelajaran, menggunakan metode instruksional seperti contoh dan latihan dalam setiap pembelajarannya, menggunakan kata-kata dan gambar untuk menyampaikan materi pembelajaran, peserta didik diberikan kesempatan untuk belajar mandiri sehingga mampu membangun pemahaman dan ketrampilan yang baik secara virtual/digital atau online. Tentu hal ini dimaksudkan untuk menghindari 
kontak langsung antar individu dengan kelompok guna mengurangi penyebaran covid-19. Selain itu, dengan menggunakan bantuan teknologi informasi dan komunikasi tersebut dan adanya alat-alat itu dapat mengubah pikiran manusia, cara belajar, cara kerja dan cara hidupnya, demikian juga, pendidikan tidak terlepas dari pengaruh teknologi. Kejadian ini dapat diidentifikasikan sebagai kemajuan dan perkembangan ilmu pengetahuan teknologi, informasi dan komunikasi Nasution, (2008:99). Pengetahuan dan pembelajaran merupakan dua hal yang tidak dapat dipisahkan satu sama lain. Pengetahuan yang didapat oleh seseorang takkan pernah ada bila tanpa melalui proses pembelajaran. Sedangkan hakekat daripada pembelajaran itu sendiri adalah untuk memperoleh pengetahuan dan untuk memperoleh hal-hal tersebut, dapat dilakukan dengan mengikuti pelatihan atau dapat juga dengan membaca buku.

Walaupun dari manfaat-manfaat tersebut di atas, juga terdapat beberapa kendala tentang pembelajaran berbasis e-learning, antara lain; pertama masalah ekonomi, tidak semua orang tua siswa memiliki penghasilan yang sama di atas ratarata sehingga menyebabkan peserta didik keteteran dalam menyiapkan alat-alat elektronik berupa komputer, laptop, hp berandroid dan paketan internet. Kedua, masalah wilayah yang tidak semua tempat terdapat akses internet yang baik. Ketiga, pengawasan dan evaluasi terhadap pembelajaran tidak bisa dipantau langsung dan tidak maksimal dan. Keempat, SDM baik pendidik maupun peserta didik kemampuanya yang berbeda-berbeda. Namun yang lebih penting untuk diperhatikan sebagai bentuk catatan adalah siswa harus menggunakan masa belajar jarak jauh ( $e$ learning) selama pandemi ini dengan sebaik mungkin dan kegiatan belajar harus tetap dilaksanakan serta siswa diawasi oleh orangtua untuk tidak menggunakan waktu belajar di rumah ini untuk bepergian, bermain berlebihan dan sejenisnya.

\section{CONCLUSIONS}

Dalam pencegahan penyebaran COVID-19, teknologi infomasi dan komunikasi dapat dimanfaatkan untuk memproses dan menstransfer dari perangkat yang satu dengan yang lain. E-Learning juga bergantung pada penyelenggara suatu kegiatan, tujuan dan penggunannya. Melalui proses pembelajaran seperti ini dapat menggunakan berbagai cara komunikasi yang berbeda, baik secara bersama-sama (kelompok) maupun perorangan (individual) Pelaksanaan E-Learning seperti dilakukan dengan moodle video conference. Dalam video conference, pemberi materi dapat memberikan materi melalui audio dan visual secara langsung pada peserta didik atau siswa selian itu juga bisa mengurangi kontak bodi sehingga dapat mencegah penyebaran Covid-19 tersebut walaupun di lain sisi masih terdapat kekurangan dari pembelajaran jarak jauh (e-learning).

\section{ACKNOWLEDGEMENTS (OPTIONAL)}

Peneliti mengucapkan terima kasih kepada PGMI Fakultas Tarbiyah Universitas Islam Jember atas dukungan dan bantuan terlaksananya hasil penelitian ini.

\section{REFERENCES}

Allen, Michael, (2013). Michael Allen's Guide to E-learning. Canada:John Wiley \& Sons. 
Intan Mutia dan Leonard, (2013). Kajian Penerapan E-Learning Dalam Proses Pembelajaran di Perguruan Tinggi. Jurnal Faktor Exacta.

I Putu Darmika, et. all. (2017). Penggunaan E-Learning Dalam Pembelajaran Bahasa Indonesia Di SMA Negeri Bali Mandara. Jurnal Jurusan Pendidikan Bahasa dan Sastra Indonesia.

L. Tjokro, Sutanto, (2009). Presentasi yang Mencekam. Jakarta: Elex Media Komputindo. Mohammad Yazdi, (2012). E-Learning Sebagai Media Pembelajaran Interaktif Berbasis Teknologi Informasi. Jurnal Ilmiah Foristek.

Munir, (2009). Pembelajaran Jarak Jauh Berbasis Teknologi Informasi dan Komunikasi. Bandung: Alfabeta.

Nasution, (2008). Teknologi Pendidikan. Jakarta: PT. BumiAksara.

Numiek Sulistyo Hanum, (2013). Keefektifan E-learning sebagai media pembelajaran (Studi Evaluasi Model Pembelajaran E-learning SMK Telkom Sandhy Putra Purwokerto). Jurnal Pendidikan Vokasi.

Nursalam dan Ferry Efendi, (2008). Pendidikan dalam Keperawatan. Jakarta: Salemba Medika.

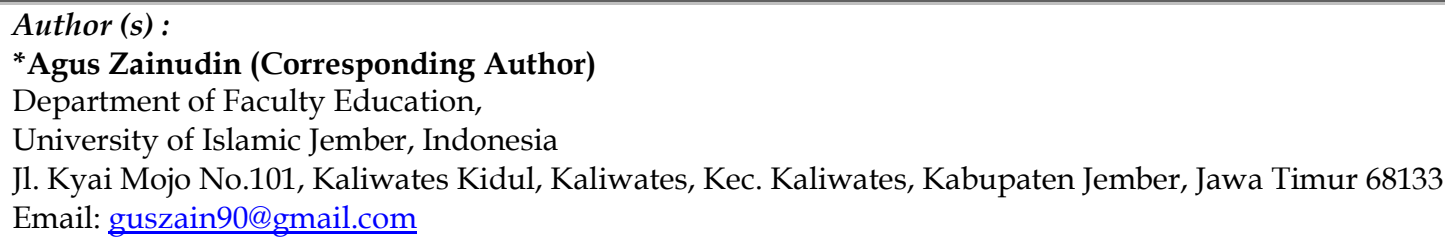

